\title{
Exploration of low-cost agro-industrial waste substrate for cellulase and xylanase production using Aspergillus heteromorphus
}

\author{
Somvir Bajar ${ }^{1,2} \cdot$ Anita Singh $^{1,3} \cdot$ Narsi R. Bishnoi $^{1}$
}

Received: 8 January 2019 / Accepted: 19 May 2020 / Published online: 1 June 2020

(c) The Author(s) 2020

\begin{abstract}
The current study was executed to explore the nutritive potential of low-cost agro-industrial waste substrates including anaerobically treated distillery spent wash (ADSW) and rice straw (RS) for enzyme production (cellulase and xylanase). The statistical model, Box-Behnken Design (BBD), was utilized to optimize the enzyme production through Aspergillus heteromorphus under liquid state bioconversion on examining the interactive interaction between substrate (ADSW), cosubstrate (RS), temperature and initial $\mathrm{pH}$. The BBD results revealed that the optimum levels of different factors for enzymes production were $6 \% \mathrm{ADSW}, 3 \% \mathrm{RS}, \mathrm{pH} 5$ and temperature $32.5{ }^{\circ} \mathrm{C}$. The highest exoglucanase, xylanase and endoglucanase enzyme activities under optimum conditions were $6.3 \mathrm{IU} / \mathrm{mL}, 11.6 \mathrm{IU} / \mathrm{mL}$ and $8.1 \mathrm{IU} / \mathrm{mL}$, respectively. The results confined that the agro-industrial waste substrate could be a cost-effective and eco-friendly alternative to produce value-added products like enzymes.
\end{abstract}

Keywords Enzyme $\cdot$ Rice straw $\cdot$ Distillery spent wash $\cdot$ Overlay contour plots $\cdot$ BBD

\section{Introduction}

The management of agro-industrial waste is very important as it poses a serious threat to the environment. A large amount of agro-industrial waste like rice straw, wheat straw, rice husk, bagasse, industrial effluents, sludge, etc., are produced annually, which create problem associated with disposal of these solid and liquid waste. The management of by-products is an augmented approach to achieve low carbon dioxide emissions (Weber and Stadlbauer 2017). The agricultural residues left after harvesting are either burned on-site (which creates air pollution and affects soil quality) or stored in the form of heaps in the field. Therefore, management of the agricultural waste is becoming one of the serious issues nowaday. However, solid

Anita Singh

anitasaharan@gmail.com

1 Department of Environmental Science and Engineering, Guru Jambheshwar University of Science and Technology, Hisar, Haryana 125001, India

2 Department of Environmental Sciences, J.C. Bose University of Science \& Technology, YMCA, Faridabad, Haryana 121006, India

3 Department of Environmental Sciences, Central University of Jammu, Samba, Jammu and Kashmir 181143, India waste can be utilized as a potential source for the production of a variety of value-added industrially useful products including enzyme, chemicals, biofuel and animal feed (Mohana et al. 2008; Mathioudakis et al. 2017). The industrial effluent like distillery spent wash produced from ethanol manufacturers generates a large volume of high strength wastewater that poses a serious threat to the water quality of surrounding area. India being the second largest producer of alcohol, contribute to huge amount of spent wash through distilleries (Mohana et al. 2009). Around 400 distillery units are operated in India, which produce around 3800 million L of alcohol (MOEFCC, India). On an average, each distillery produces 8-15 L of spent wash for generation of each liter of alcohol, depending upon raw material used, quality of raw material and process (Saha et al. 2005). Considering its polluting nature, distilleries are counted as one of the 17 most polluting "Red Category" industries (Krishnamoorthy et al. 2017). The wastewater generated in form of spent wash is enriched with high quantity of dissolved organic and inorganic content. Proper handling and disposal of the wastewater is required to avoid any damage to the environment. Therefore, environment regulation authorities are much concerned and enacted strict norms and regulate proper discharge of industrial effluents into the environment (Mohana et al. 2009). The discharge of untreated or partially treated ADSW into the environment may cause serious health 
and ecotoxicological threats (Chowdhary et al. 2018). Several approaches are widely utilized for the treatment of distillery wastewater including physical, chemical and biological, but anaerobic treatment is widely accepted practice (Pettigrew et al. 2015). Though, anaerobically treated effluent cannot be discharge directly into the environment due to enriched proportion of organic matter in form of biochemical oxygen demand (BOD) and chemical oxygen demand (COD) (Nandy et al. 2002). The anaerobically treated wastewater contains micro-(potassium, sodium, nitrogen, phosphorus) and macro( $\mathrm{Ca}, \mathrm{Cu}, \mathrm{Mn}$, and $\mathrm{Zn}$ ) nutrients, which can be utilized to meet the requirement of crops through irrigation fields and production of value-added products like enzyme, biosurfactant, polyunsaturated fatty (Mohana et al. 2008; Chapla et al. 2010; Singh et al. 2010).

The agro-industrial waste can be used for the production of commercially important products like enzyme due to their nutritional potential. Enzymes like cellulase and xylanase have industrial importance and widely used in various industries including textile, pulp and paper, laundry and detergent, wine and brewery, food processing, agricultural industries and bio-ethanol production (Mohana et al. 2008; Kuhad et al. 2011). The cost of these enzymes is a big issue faced by these industries, and efforts are going on to reduce the cost by strain improvement, better fermentation and recovery system and utilization of easily available low-cost substrates (Xu et al. 2005; Ahamed and Vermette 2008). Enzymes like cellulase and xylanase play a very significant role in lignocellulosic biomass to biofuel conversion process. Therefore, production of cellulase and xylanase enzymes from underrated biomass rice straw and industrial effluent anaerobically treated distillery spent wash can be economically beneficial in various industries. In the previous study (Singh et al. 2010), comparison of ADSW and mineral media for laccase production was studied and found that ADSW gives better results than mineral media. Media components, and their concentration, substrate, fungal species and process parameters play a very important role in maximizing cellulase enzyme production (Hu et al. 2018; Sreena and Sebastian 2018). Therefore, aim of the present study was to explore the feasibility and optimization of ADSW and rice straw substrates for enzyme production. Box-Behnken Design (BBD) of response surface methodology (RSM) was exploited further to assess the interactive effects of substrates (ADSW and RS) and other parameters (initial $\mathrm{pH}$ and temperature) on production of beneficial enzyme by fungi $A$. heteromorphus.

\section{Materials and methods}

\section{Substrate, fungal culture and inoculum preparation}

Anaerobically treated distillery spent wash (ADSW) and rice straw (RS) (Singh et al. 2010) were used as a substrate and co-substrate, respectively, for enzyme (cellulase and xylanase) production. Fungal strain Aspergillus heteromorphus (MTCC 8625) was maintained on potato dextrose agar (PDA) plates for spore production. The fungal strain was cultured on PDA slant for 07 days and incubated at constant temperature condition of $32{ }^{\circ} \mathrm{C}$. After a week of incubation, sterilize distilled water was added to the slant and spore suspension was made by scraping of surface gently with sterilized glass rod. The spore concentration in aqueous suspensions was determined using a hemocytometer.

\section{Experimental procedure for cellulase and xylanase production}

Rice straw (1-5\% (w/v)) was added to $50 \mathrm{~mL}$ of $2-10 \%$ (w/v) anaerobically treated distillery spent wash (ADSW) in $250 \mathrm{~mL}$ Erlenmeyer flask as per design matrix of Box-Behnken Design (BBD) (Table 1). pH of the mixture was maintained from a range of 4.0-6.0 by adding $1 \mathrm{~N} \mathrm{HCl}$ or $1 \mathrm{~N} \mathrm{NaOH}$. The sample was sterilized in autoclave at temperature $121^{\circ} \mathrm{C}$ and pressure condition at $15 \mathrm{psi}$ for $30 \mathrm{~min}$. After sterilization samples were inoculated with fungal spore inocula of $1.8 \times 10^{8} / \mathrm{mL}$. The samples were incubated at temperature varied from $30{ }^{\circ} \mathrm{C}$ to $35^{\circ} \mathrm{C}$ in incubator shaker at agitation speeds of 125 RPM for enzyme production. Samples were collected after 05 days of fermentation to analyze the enzymatic activities.

\section{Box-Behnken design for optimization of the parameters for cellulase production}

Microbial growth and activities are deeply affected by nutrients and process parameters. Moreover, the nutritional and non-nutritional parameters play an important role in enzyme production by microbes. Therefore, in the present study, 04 important parameters including substrate concentration (Anaerobically treated Distilleries Spent Wash (ADSW), 2-10\%) (A); co-substrate concentration (Rice Straw (RS), $1-5 \%)(B)$; initial $\mathrm{pH} 4.0-6.0(\mathrm{C})$ and temperature $30-35{ }^{\circ} \mathrm{C}$ (D) were chosen as the independent variables for production of cellulase and xylanase enzyme as dependent response (Table 1). Box-Behnken Design (BBD) of Response Surface Methodology (Box and Wilson 1951) was used to study the optimum conditions for enzyme production and to explore the interactive effect of 04 independent factors on enzyme production. In Box-Behnken Design, each variable was studied at 03 levels; therefore, a total of 27 experiments were designed by the software for the current study. Overall second-order polynomial mathematical relationship was used to express enzyme activity $\left(Y_{1}\right)$ a function of independent variables as follows: 
Table 1 Experimental design in terms of coded factors and results of the Box-Behnken model

\begin{tabular}{|c|c|c|c|c|c|c|c|}
\hline Sr. no. & $\begin{array}{l}\text { Sub. conc. } \\
(\% \mathrm{w} / \mathrm{v})\end{array}$ & $\begin{array}{l}\text { Co-sub. conc. } \\
(\% \mathrm{w} / \mathrm{v})\end{array}$ & $\mathrm{pH}$ & Temp. $\left({ }^{\circ} \mathrm{C}\right)$ & $X$ & $Y$ & $Z$ \\
\hline 1 & -1 & -1 & 0 & 0 & 2.5 & 7.5 & 7.3 \\
\hline 2 & 1 & -1 & 0 & 0 & 2.1 & 7.2 & 7.1 \\
\hline 3 & -1 & 1 & 0 & 0 & 3.2 & 7.6 & 7.9 \\
\hline 4 & 1 & 1 & 0 & 0 & 3.2 & 8 & 8.1 \\
\hline 5 & 0 & 0 & -1 & -1 & 3.3 & 7.8 & 7.9 \\
\hline 6 & 0 & 0 & 1 & -1 & 3.0 & 8.1 & 7.9 \\
\hline 7 & 0 & 0 & -1 & 1 & 3.4 & 8.5 & 8.5 \\
\hline 8 & 0 & 0 & 1 & 1 & 3.6 & 8.6 & 8.5 \\
\hline 9 & -1 & 0 & 0 & -1 & 2.5 & 7.7 & 7.4 \\
\hline 10 & 1 & 0 & 0 & -1 & 2.6 & 7.9 & 8.1 \\
\hline 11 & -1 & 0 & 0 & 1 & 2.9 & 8.1 & 8.3 \\
\hline 12 & 1 & 0 & 0 & 1 & 2.4 & 7.8 & 8 \\
\hline 13 & 0 & -1 & -1 & 0 & 2.7 & 7.6 & 7.7 \\
\hline 14 & 0 & 1 & -1 & 0 & 3.6 & 8.4 & 8.3 \\
\hline 15 & 0 & -1 & 1 & 0 & 2.9 & 7.9 & 7.5 \\
\hline 16 & 0 & 1 & 1 & 0 & 3.8 & 8.1 & 8.3 \\
\hline 17 & -1 & 0 & -1 & 0 & 1.8 & 6.6 & 6.7 \\
\hline 18 & 1 & 0 & -1 & 0 & 1.6 & 6.8 & 6.8 \\
\hline 19 & -1 & 0 & 1 & 0 & 1.8 & 6.8 & 6.7 \\
\hline 20 & 1 & 0 & 1 & 0 & 2.1 & 6.8 & 6.8 \\
\hline 21 & 0 & -1 & 0 & -1 & 3.8 & 8.9 & 8.7 \\
\hline 22 & 0 & 1 & 0 & -1 & 4.9 & 9.5 & 9 \\
\hline 23 & 0 & -1 & 0 & 1 & 4.3 & 9.1 & 9.3 \\
\hline 24 & 0 & 1 & 0 & 1 & 5.3 & 9.8 & 7.3 \\
\hline 25 & 0 & 0 & 0 & 0 & 6.3 & 11.5 & 7.1 \\
\hline 26 & 0 & 0 & 0 & 0 & 6.5 & 11.5 & 7.9 \\
\hline 27 & 0 & 0 & 0 & 0 & 6.3 & 11.6 & 8.1 \\
\hline 28 & -1 & -1 & 0 & 0 & 6.2 & 10.9 & 8 \\
\hline 29 & 1 & -1 & 0 & 0 & 6.1 & 11.4 & 7.8 \\
\hline
\end{tabular}

$X=$ Cellulase/exoglucanase enzyme activity (IU/mL) by A. heteromorphus

$Y=$ Xylanase enzyme activity $(\mathrm{IU} / \mathrm{mL})$ by $A$. heteromorphus

$Z=$ CMCase/endoglucanase enzyme activity (IU/mL) by A. heteromorphus

$$
\begin{aligned}
Y_{1}= & b_{0}+b_{1} A+b_{2} B+b_{3} C+b_{4} D+b_{11} A^{2}+b_{22} B^{2} \\
& +b_{33} C^{2}+b_{44} D^{2}+b_{12} A B+b_{13} A C+b_{14} A D \\
& +b_{23} B C+b_{24} B D+b_{34} C D
\end{aligned}
$$

where $Y_{1}$ is the predicted response; $b_{0}$ is the intercept; $b_{1}$, $b_{2}, b_{3}, b_{4}$ are linear coefficients; $b_{11}, b_{22}, b_{33}, b_{44}$ are squared coefficients; $b_{12}, b_{13}, b_{14}, b_{23}, b_{24}, b_{34}$ are interaction coefficients with independent variables, $A$ (substrate concentration), $B$ (co- substrate concentration), $C(\mathrm{pH})$ and $D$ (temperature). The results of the experimental design were analyzed and interpreted using Minitab (trial version 15.0) and 'Design Expert"' software (trial version 8.1.1, StatEase, Inc., Minneapolis, USA).

\section{Enzyme extraction and analytical analysis}

The microcosm containing the substrate and co-substrate under defined incubation condition as per design order was recovered after 05 days and homogenize for further processing of the samples. The homogenate from each flask was filtered through muslin cloth, and the filtrate was centrifuged in refrigerated centrifuge at $4{ }^{\circ} \mathrm{C}$ on $7200 \mathrm{RPM}$ for $20 \mathrm{~min}$. The supernatant was further used to analyze enzyme activities. Filter paper activity (exoglucanse) and endoglucanase (CMCase) activity were determined following the Ghose's method as suggested in the literature (Ghose 1987). The xylanase activity was determined by using oat spelt xylan as substrate (Singh and Bishnoi 2013). The reduced sugars released were analyzed using the DNS assay (Miller 1959). Cellulose, hemicellulose 
and lignin content were estimated by the method of Goering and Van Soest (1970).

\section{Results and discussion}

Box-Behnken Design (BBD) was used to study the linear, quadratic and interactive effects of independent variables considered for the current study on cellulase and xylanase enzyme production by $A$. heteromorphus. The polynomial equation, describing the cellulase and xylanase enzyme production by $A$. heteromorphus as a simultaneous function of the ADSW $(A)$, RS $(B)$, initial $\mathrm{pH}(C)$ and temperature $(D)$, is shown in Eqs. (2-4).

$$
\begin{aligned}
X= & +6.16-0.067 * A+0.47 * B+0.092 * C+0.15 * D \\
& -2.66 * A^{2}-0.92 * B^{2}-2.02 * C^{2}-0.96 * D^{2} \\
& +0.10 * A * B+0.13 * A * C-0.17 * A * D \\
& +0.000 * B * C-0.075 * B * D+0.10 * C * D \\
Y= & +11.38+0.017 * A+0.27 * B+0.050 * C+0.17 * D \\
& -2.55 * A^{2}-1.20 * B^{2}-2.15 * C^{2}-0.93 * D^{2} \\
& +0.18 * A * B-0.050 * A * C-0.13 * A * D \\
& -0.15 * B * C+0.025 * B * D-0.050 * C * D
\end{aligned}
$$

$$
\begin{aligned}
Z= & +7.78+0.050 * A+0.11 * B-0.017 * C+0.075 * D \\
& -0.58 * A^{2}+0.33 * B^{2}-0.28 * C^{2}+0.64 * D^{2} \\
& +0.10 * A * B+0.000 * A * C-0.25 * A * D \\
& +0.050 * B * C-0.058 * B * D+0.000 * C * D
\end{aligned}
$$

where $X, Y$ and $Z$ are observed response as cellulase enzyme activity $(\mathrm{IU} / \mathrm{mL})$, xylanase enzyme activity $(\mathrm{IU} / \mathrm{mL})$ and endoglucanase or CMCase enzyme activity (IU/mL), respectively. The coefficient of determination $\left(R^{2}\right)$ was used to check the fitness of the model. The closer value of the $R^{2}$ to 1 showed a good fit between the predicted response and experimental values. The coefficient of determination $R^{2}$ for the above-predicted Eqs. (2), (3) and (4) was $99.27 \%$, $99.16 \%$ and $72.8 \%$, respectively. The estimated regression coefficient $\left(R^{2}\right)$ and corresponding $p$ value for the cellulase and xylanase enzyme activities are shown in Table 2 . The results revealed that the coefficient for the quadratic effects of ADSW, RS, initial $\mathrm{pH}$, and temperature was highly significant for all responses.

As shown in Table 1, cellulase enzyme activity varied from 1.6 to $6.5 \mathrm{IU} / \mathrm{mL}$, whereas xylanase and endoglucanase enzyme activities showed variations from 6.6 to $11.6 \mathrm{IU} /$ $\mathrm{mL}$ and $6.7-8.1 \mathrm{IU} / \mathrm{mL}$, respectively, under variable conditions, as prescribed in BBD design order. Overlaid contour plots Fig. 1a-f showed interactive effect of the studied variables- $\mathrm{pH}$, temperature, RS conc. and ADSW conc. on enzyme production as dependent variable. Multiple contour plots are overlaid over one another in a single graph, and the white area in these overlaid contour plots will shows the range of two variables where the criteria for all response variables are satisfied. These plots are used to find the best-

\begin{tabular}{|c|c|c|c|c|c|c|}
\hline \multirow[t]{2}{*}{ Source } & \multicolumn{2}{|c|}{ Cellulase } & \multicolumn{2}{|c|}{ Xylanase } & \multicolumn{2}{|l|}{ CMCase } \\
\hline & Coff & $p$-value & Coff & $p$-value & Coff & $p$-value \\
\hline Constant & 6.16 & 0.00 & 11.38 & $<0.0$ & 7.78 & 0.03 \\
\hline$A$ & -0.067 & 0.233 & 0.01 & 0.77 & 0.05 & 0.73 \\
\hline$B$ & 0.47 & 0.00 & 0.26 & 0.00 & 0.10 & 0.46 \\
\hline C & 0.092 & 0.108 & 0.05 & 0.39 & -0.01 & 0.90 \\
\hline$D$ & 0.15 & 0.014 & 0.16 & 0.01 & 0.075 & 0.61 \\
\hline$A^{2}$ & -2.66 & 0.00 & -2.55 & $<0.00$ & -0.57 & 0.01 \\
\hline$B^{2}$ & -0.92 & 0.00 & -1.20 & $<0.00$ & 0.33 & 0.11 \\
\hline$C^{2}$ & -2.02 & 0.00 & -2.15 & $<0.00$ & -0.27 & 0.17 \\
\hline$D^{2}$ & -0.96 & 0.00 & -0.92 & $<0.00$ & 0.63 & 0.006 \\
\hline$A B$ & 0.10 & 0.298 & 0.17 & 0.09 & 0.1 & 0.69 \\
\hline$A C$ & 0.13 & 0.198 & -0.05 & 0.61 & 0 & 1.00 \\
\hline$A D$ & -0.17 & 0.079 & -0.12 & 0.22 & -0.25 & 0.33 \\
\hline$B C$ & 0.00 & 1.0 & -0.15 & 0.14 & 0.05 & 0.84 \\
\hline$B D$ & -0.075 & 0.43 & 0.02 & 0.80 & -0.57 & 0.03 \\
\hline$C D$ & 0.10 & 0.298 & -0.05 & 0.61 & 0 & 1.00 \\
\hline Lack of fit & & 0.054 & & 0.94 & & 0.29 \\
\hline
\end{tabular}
operating conditions for maximizing the response. Figure 1a showed the interactive effect of rice straw (RS) and ADSW concentration on enzyme activities (exoglucanase, xylanase and endoglucanase), and as per the white portion of overlay contour plots highest enzyme activities observed at middle value of both variables. Exoglucanase and xyalanse
Table 2 Estimated regression coefficient and corresponding $p$ value for cellulase, xylanase and CMCase production by $A$. heteromorphus

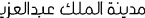

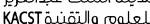



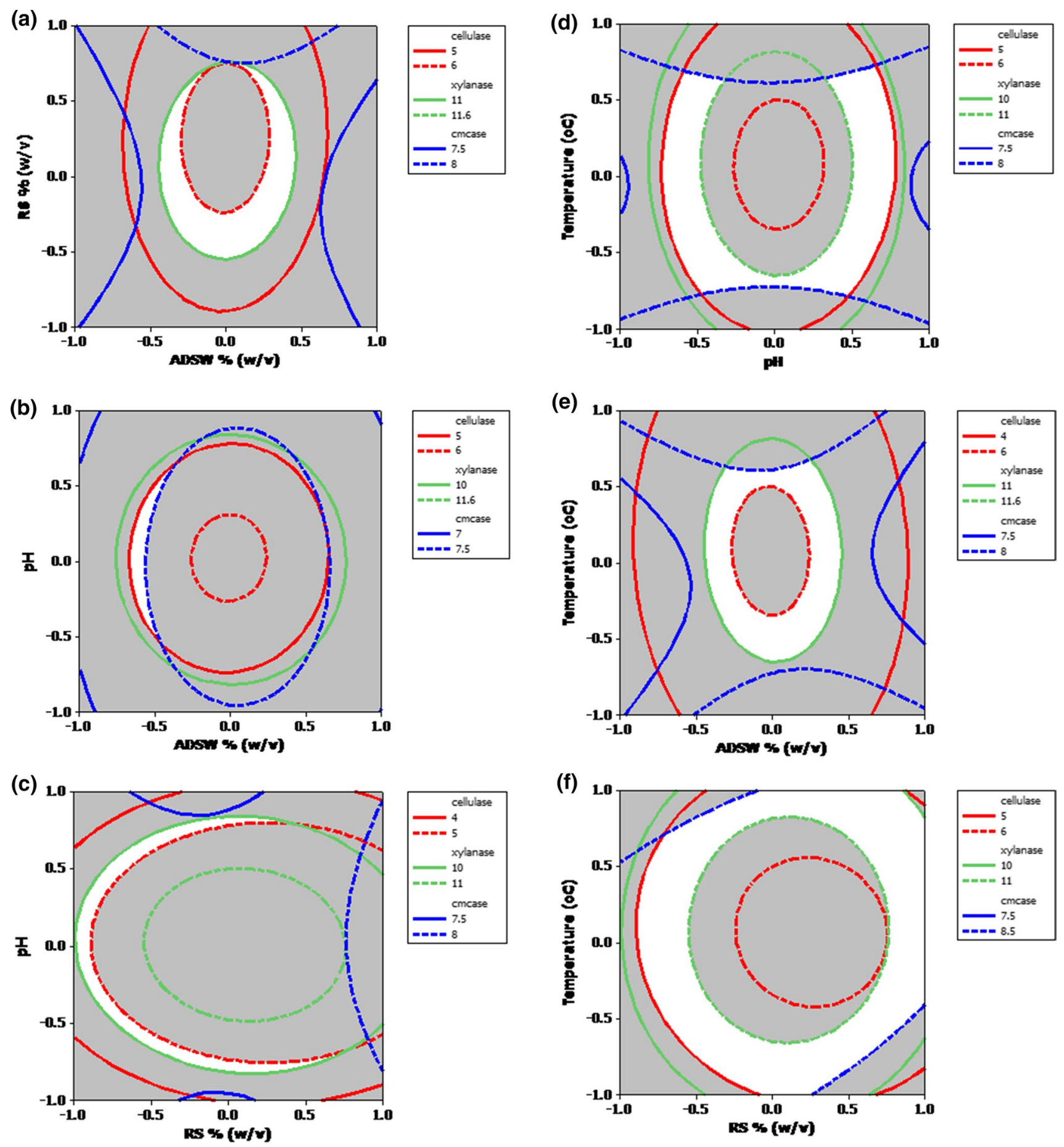

Fig. 1 Overlaid contour plot for the effects of a ADSW (\% v/v) and RS (\% w/v), b pH and ADSW (\% v/v), c pH and RS (\%w/v), d pH and temperature $\left({ }^{\circ} \mathrm{C}\right)$, e temperature $\left({ }^{\circ} \mathrm{C}\right)$ and $\operatorname{ADSW}(\% \mathrm{v} / \mathrm{v}), \mathbf{f} \mathrm{RS}(\% \mathrm{w} / \mathrm{v})$ and temperature $\left({ }^{\circ} \mathrm{C}\right)$, on enzyme production by A. heteromorphus

activities share the same optimum range of ADSW conc. for maximum enzyme activity, but different optimum range of rice straw concentration as 3.5\% for exoglucanase and 3.0\% for xylanase activity. Highest endoglucanase activity was observed at $6.3 \%$ ADSW conc. and $4.7 \%$ rice straw conc., slightly higher than the middle value of studied variables.
Figure $1 \mathrm{~b}$ shows the interactive effect of $\mathrm{pH}$ and ADSW conc. on enzyme activities. The white portion of Fig. $1 \mathrm{~b}$ shows that maximum enzyme activities were observed at middle value of both ADSW conc. and $\mathrm{pH}$, i.e., $4-8 \%$ of ADSW and 4.5-5.5 of $\mathrm{pH}$. 
The concentration of substrate exhibits linear behavior with the enzymes activities up to the middle tested level; however, the substrate concentration at higher level (10\%) affects adversely the cellulase, xylanase and endogluconase production by $A$. heteromorphus. The antagonistic relationship of ADSW at higher concentration with the enzyme production by $A$. heteromorphus might be because of toxicity caused by higher ADSW concentration to the microbes, which adversely affects the culture growth and enzyme activity. The distillery effluent is enriched in organic content (BOD, COD, TOC) along with various macro- and micro-nutrient including total nitrogen, calcium, potassium, phosphates, phenolic compounds, sulfates and other solids which help in microbial growth (Singh et al. 2010). Chapla et al. (2010) studied the xylanase enzyme production by $A$. foetidus MTCC 4898 on utilizing ADSW and wheat bran as substrate and co-substrate, respectively. Further, it was claimed that $A$. foetidus exhibited higher yield of xylanase enzyme production and specific activity with ADSW when compared to MS media and tap water. Acharya et al. (2010) studied cellulase enzyme production by fungus $A$. ellipticus using ADSW and revealed that the fungi flourished very well and support enzyme production, even in soaring concentrations of distillery effluent.

The carbon source supplied to microorganisms is also crucial for enzyme production; therefore, the selection of carbon source is very important. The interaction between RS conc. and $\mathrm{pH}$ on all enzyme activities is shown in Fig. 1c. In this case, $\mathrm{pH} 5.0$ was optimum for all enzyme activities, but optimum range of RS conc. varied as $3.4 \%$ for exoglucanase activity, $3.0 \%$ for xylanase activity and $4.7 \%$ for endoglucanase activity. Different types of carbon substrates like rice straw, wheat straw, rice husk, wheat bran, water hyacinth, sugarcane bagasse, saw dust were studied for enzyme production depending upon the need, availability, accessible surface area, particle size and physical properties of the substrate, considering their crucial role in solid state fermentation (Archana and Sayyanarayana 1997; Chapla et al. 2010). In the present study, rice straw was used as a carbon source for enzyme (cellulase, xylanase and endoglucanase) production, considering their biochemical composition, containing 38\% cellulose, hemicellulose $26 \%$ and $7 \%$ lignin content. Lignocellulosic biomass is an underutilized source of biomass on planet earth, which can be used as substrate for enzyme production. Lignocellulosic biomass provides surface as well as carbon source required for microbial growth. Kulkarni et al. (1999) reported that both xylanase and cellulase enzymes were produced when cellulose and hemicellulose were used together as carbon source. Cellulase and xylanase both are inducible enzymes, and the presence of cellulose and xylan in media acted as good inducers for enzyme production (Aro et al. 2001; Nair et al. 2008).
The effect of initial $\mathrm{pH}$ on enzyme activities shows that as the $\mathrm{pH}$ increases cellulase and xylanase activities increase but up to mid-level only, further increase in $\mathrm{pH}$ decreases enzyme activity as shown in Table 1 . The overlay contour plot of interactions between $\mathrm{pH}$ and temperature affecting enzyme activities is shown by Fig. 1d. Figure 1d shows that highest enzyme activities observed at middle level of $\mathrm{pH}$ (5.0) and temperature $\left(32.5^{\circ} \mathrm{C}\right)$ except for endoglucanase activity where optimum temperature was $34{ }^{\circ} \mathrm{C}$. The initial $\mathrm{pH}$ of the medium is very important and critical parameter as it affects the microbial morphology, growth of mycelia, enzymatic processes and transport of various components across the cell membrane (Kapoor et al. 2008), pellet formation and coagulation of spores (Galbraith and Smith 1969). Most suitable pH range is $4.5-5.5$ for the growth of most of the fungal species and their metabolites; the reason might be the suitability of extracellular enzymes at this $\mathrm{pH}$, and change in this $\mathrm{pH}$ range may leads to denaturation of enzymes (Latifian et al. 2007). Cellulase production is affected by $\mathrm{pH}$ in many ways like pelleted morphology, hydrogen ion effect and stability (Kalra and Sandhu 1986). Dispersed morphology found to be associated with increased cellulase production, while pelleted morphology decrease cellulase enzyme production which might be due to hindered internal gas-liquid mass transfer (Papagianni 2004). Both these morphologies are $\mathrm{pH}$ dependent, and higher $\mathrm{pH}$ leads to pelleted morphology. Matkar et al. (2013) studied cellulase enzyme production under submerged fermentation by $A$. sydowii and obtained maximum enzyme activity at pH 5.5. Aggarwal et al. (2017) also found highest cellulase production by A. nigerBK01 at $\mathrm{pH}$ 5.5. Shrivastava et al. (1984) found maximum enzyme activity by $A$. wentii $\mathrm{Pt}$ 2804 over a $\mathrm{pH}$ range of $4.5-5.5$ but declined sharply beyond 5.5. Ncube et al. (2012) used Jatropha curcas seed cake for cellulase enzyme production by $A$. niger and found optimum pH 5.0 for maximum cellulase activity. Jecu (2000) studied endoglucanase enzyme production by A. niger 38 using a combination of wheat straw and wheat bran as substrate and found that maximum enzyme activity was found at initial $\mathrm{pH}$ range 4.5-5.5.

Incubation temperature plays an important role in the production of enzymes and metabolic activities of a microorganism. The enzyme is a secondary metabolite, and its yield is greatly affected by the incubation temperature (Kumar et al. 2016). So, the optimum temperature is very important for enzyme production because both higher and lower temperature than the optimum value affects the process. The lower temperature affects the transport of nutrients and at higher temperature more energy is spent by the microorganism for maintaining the process (Pirt 1975). In the present study, optimization of temperature and its interaction with other variables were studied. Figure 1e showed interaction between ADSW conc. and temperature on enzyme activities, 
Table 3 Comparative study of enzyme activities under submerged fermentation from Aspergillus strains grown on different carbon source

\begin{tabular}{|c|c|c|c|c|c|}
\hline \multirow[t]{2}{*}{ Organism } & \multirow[t]{2}{*}{ Substrate } & \multicolumn{3}{|c|}{ Enzyme activities } & \multirow[t]{2}{*}{ References } \\
\hline & & FPase & CMCase & Xylanase & \\
\hline Aspergillus nidulans ATCC62041 & Delignified bagasse & $0.26 \mathrm{U} / \mathrm{ml}$ & $3.0 \mathrm{U} / \mathrm{ml}$ & - & Bagga et al. (1987) \\
\hline Aspergillus niger SBS6 & Wheat bran & - & $1.76 \mathrm{IU} / \mathrm{ml}$ & $35.0 \mathrm{IU} / \mathrm{ml}$ & Nair et al. (2008) \\
\hline Aspergillus niger SBS47 & Wheat bran & - & $2.0 \mathrm{IU} / \mathrm{ml}$ & $32.0 \mathrm{IU} / \mathrm{ml}$ & Nair et al. (2008) \\
\hline Aspergillus terreus & Oil palm empty fruit bunch & $2.29 \mathrm{U} / \mathrm{ml}$ & $50.33 \mathrm{U} / \mathrm{ml}$ & - & Shahriarinour et al. (2011) \\
\hline Aspergillus flavus SBS65 & Wheat bran & - & - & $6.0 \mathrm{IU} / \mathrm{ml}$ & Nair et al. (2008) \\
\hline Aspergillus fumigatus (CWSF-7) & Treated grass biomass & $0.9 \mathrm{IU} / \mathrm{ml}$ & $1.9 \mathrm{IU} / \mathrm{ml}$ & - & Mohapatra et al. (2018) \\
\hline Aspergillus sydowi & Sugarcane bagasse & $1.33 \mathrm{IU} / \mathrm{ml}$ & $1.32 \mathrm{IU} / \mathrm{ml})$ & - & Matkar et al. (2013) \\
\hline Aspergillus heteromorphus & Rice straw & $6.3 \mathrm{IU} / \mathrm{ml}$ & $11.6 \mathrm{IU} / \mathrm{ml}$ & $8.1 \mathrm{IU} / \mathrm{ml}$ & This work \\
\hline
\end{tabular}

FPase filter paper activity, CMCase carboxymethylcellulase activity

and maximum enzyme activities were observed with $6 \%$ ADSW concentration. While in case of temperature optima, highest exoglucanase and xylanase activities were observed at $32.5{ }^{\circ} \mathrm{C}$, while $34{ }^{\circ} \mathrm{C}$ for endoglucanase activity. Figure $1 \mathrm{f}$ depicted the interaction between RS conc. and temperature, and their effect on enzyme activities. In this overlay contour plot, optimum RS conc. was $3.0 \%$ for all enzyme activities. In case of temperature, similar trend is observed as in Fig. 1e in all enzyme activities. Any increase in temperature beyond optimum range had a drastic adverse effect on the enzyme production. Jecu (2000) also observed that temperature above $34^{\circ} \mathrm{C}$ leads to decrease in biosynthesis of enzyme by $A$. niger, might be due to temperature deactivation. Gilna and Khaleel (2011) studied cellulase enzyme production by fungus $A$. fumigates and found $32{ }^{\circ} \mathrm{C}$ as optimum temperature for cellulase production. The higher temperature causes cell death due to alteration in the cell membrane composition and stimulate protein catabolism (Bansal et al. 2012).

Table 3 showed the comparative studies of enzyme activities obtained in present study by fungus $A$. heteromorphus with other Aspergillus strains using lignocellulosic biomass as substrate. There are many reports available which shows that different $\mathrm{pH}$, temperatures and substrates for maximum cellulase and xylanase production using Aspergillus sp. suggesting that the optimum range of these parameters for enzyme production depends on the strain variation of the microorganism (Murao et al. 1988; Lu et al. 2003; Gautam et al. 2011). The crude on-site produced from the present study can be used for hydrolysis of lignocellulosic biomass. Acharya et al. (2010) used partially purified enzymes produced by Aspergillus ellipticus using anaerobically treated distillery spent wash and wheat straw as substrate for saccharification of wheat straw, wheat bran, rice straw, corn cobs and crystalline cellulose. Deswal et al. (2011) studied the saccharification of wheat straw by crude enzymes produced by Fomitopsis sp. RCK2010 and found reducing sugars production of $214.1 \mathrm{mg} / \mathrm{g}$ of the substrate. Kumar et al. (2016) studied saccharification of pearl millet stover by crude on-site produced enzymes and found reducing sugar concentration of $546.91 \mathrm{mg} / \mathrm{g}$ of substrate. The utilization of crude enzymes or partially purified enzymes in lieu of purified enzymes may reduce the cost of saccharification process.

\section{Conclusions}

In this study, anaerobically treated distillery spent wash and rice straw which were used as substrate and co-substrate, respectively, for enzyme (cellulase, exogluacanse and xylanase) production by $A$. heteromorphus. The optimum process conditions for maximum enzyme production under liquid state bioconversion were successfully determined by statistical method Box-Behnken design. The optimum conditions, for highest enzyme activities, as obtained from second order polynomial model, were the substrate $6 \%(\mathrm{v} / \mathrm{v})$, co-substrate concentration of $3 \%(\mathrm{w} / \mathrm{v})$, temperature $32.5^{\circ} \mathrm{C}, \mathrm{pH} 5$. Further investigations will be required to explore the nutritive potential of anaerobically treated distillery spent wash and underrated natural resource rice straw for enzymes-cellulase and xylanase production, so that the developed process can be used at industry level.

\section{Compliance with ethical standards}

Conflict of interest The authors declare that there is no conflict of interest regarding the publication of this article.

Open Access This article is licensed under a Creative Commons Attribution 4.0 International License, which permits use, sharing, adaptation, distribution and reproduction in any medium or format, as long as you give appropriate credit to the original author(s) and the source, provide a link to the Creative Commons licence, and indicate if changes were made. The images or other third party material in this article are included in the article's Creative Commons licence, unless indicated otherwise in a credit line to the material. If material is not included in the article's Creative Commons licence and your intended use is not

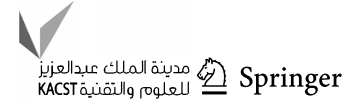


permitted by statutory regulation or exceeds the permitted use, you will need to obtain permission directly from the copyright holder. To view a copy of this licence, visit http://creativecommons.org/licenses/by/4.0/.

\section{References}

Acharya BK, Mohana S, Jog R, Divecha J, Madamwar D (2010) Utilization of anaerobically treated distillery spent wash for production of cellulases under solid-state fermentation. J Environ Manag 91:2019-2027

Aggarwal NK, Goyal V, Saini A, Yadav A, Gupta R (2017) Enzymatic saachrification of pretreated rice straw by cellulase from Aspergillus niger BKo1. 3 Biotech 7:158

Ahamed A, Vermette P (2008) Enhanced enzyme production from mixed cultures of Trichoderma reesei RUT-C30 and Aspergillus niger LMA grown as fed batch in a stirred tank bioreactor. Biochem Eng J 42:41-46

Archana A, Sayyanarayana T (1997) Xylanase production by thermophilic Bacillus lichenformis A99 in solid-state fermentation. Enzyme Microb Technol 21:12-17

Aro N, Saloheimo A, Ilmén M, Penttilä M (2001) ACEII, a novel transcriptional activator involved in regulation of cellulase and xylanase genes of Trichoderma reesei. J Biol Chem 276(26):24309-24314

Bagga PS, Sandhu DK (1987) Cellulase formation by Aspergillus nidulans. J Ferment Technol 65(6):635-642

Bansal N, Tewari R, Soni R, Soni SK (2012) Production of cellulases from Aspergillus niger NS-2 in solid state fermentation on agricultural and kitchen waste residues. Waste Manag 32(7):1341-1346

Box GEP, Wilson KB (1951) On the experimental attainment of optimum conditions. J R Stat Soc (Ser B) 13:1-45

Chapla D, Divecha J, Madamwar D, Shah A (2010) Utilization of agroindustrial waste for xylanase production by Aspergillus foetidus MTCC 4898 under solid state fermentation and its application in sacchrification. Biochem Eng J 49:361-369

Chowdhary P, Raj A, Bharagava RN (2018) Environmental pollution and $d$ health hazards from distillery wastewater and treatment approaches to combat the environmental threats: a review. Chemosphere 194:229-246

Deswal D, Khasa YP, Kuhad RC (2011) Optimization of cellulase production by a brown rot fungus Fomitopsis sp. RCK2010 under solid state fermentation. Biores Technol 102(10):6065-6072

Galbraith JC, Smith JE (1969) Filamentous growth of Aspergillus niger in submerged shake culture. Trans Br Mycol Soc 52:237-246

Gautam SP, Bundela PS, Pandey AK, Khan J, Awasthi MK, Sarsaiya S (2011) Optimization for the production of cellulase enzyme from municipal solid waste residue by two novel cellulolytic fungi. Biotechnol Res Int. https://doi.org/10.4061/2011/810425

Ghose TK (1987) Measurement of cellulase activities. Pure Appl Chem 59:257-268

Gilna VV, Khaleel KM (2011) Cellulase enzyme activity of Aspergillus fumigates from mangrove soil on lignocellulosic substrate. Recent Res Sci Technol 3(1):132-134

Goering HK, Van Soest PJ (1970) Forage fiber analysis (apparatus, reagent, procedures, and some applications). In: Protas OV, Manenkova JA (eds) Agricultural handbook. Agriculture Research Service-United States Department of Agricultural, USDA, Washington, DC, pp 1-20

Hu Y, Du C, Pensupa N, Lin CSK (2018) Optimization of fungal cellulase production from textile waste using experimental design. Process Saf Environ Prot 118:133-142

Jecu L (2000) Solid state fermentation of agricultural wastes for endoglucanase production. Ind Crops Prod 11:1-5
Kalra MK, Sandhu DK (1986) Optimal production of cellulolytic enzymes and their location in Trichoderma pseudokoningii. Acta Biotechnol 6:161-166

Kapoor M, Nair LM, Kuhad RC (2008) Cost effective xylanase production from free and immobilized Bacillus pumilus strain MK001 and its application in saccharification of Prosopis juliflora. Biochem Eng J 38:88-97

Krishnamoorthy S, Premalatha M, Vijayasekaran M (2017) Characterization of distillery wastewater-an approach to retrofit existing effluent treatment plant operation with phycoremediation. J Clean Prod 148:735-750

Kuhad RC, Gupta R, Singh A (2011) Microbial cellulases and their industrial applications. Enzyme Res 2011:10. https://doi. org/10.4061/2011/280696

Kulkarni N, Shendye A, Rao M (1999) Molecular and biotechnological aspects of xylanases. FEMS Microb Rev 23(4):411-456

Kumar A, Dutt D, Gautam A (2016) Production of crude enzyme from Aspergillus nidulans AKB-25 using back gram residue as the substrate and its industrial applications. J Genet Eng Biotechnol 14:107-118

Latifian M, Hamidi-Esfahani Z, Barzegar M (2007) Evaluation of culture conditions for cellulase production by two Trichoderma reesei mutants under solid-state fermentation conditions. Bioresour Technol 98:3634-3637

Lu W, Li D, Wu Y (2003) Influence of water activity and temperature on xylanase biosynthesis in pilot-scale solid-state fermentation by Aspergillus sulphureus. Enzyme Microbial Technol 32(2):305-311

Mathioudakis V, Gerbens-Leenes PW, Van der Meer TH, Hoekstra AY (2017) The water footprint of second-generation bioenergy: a comparison of biomass feedstocks and conversion techniques. J Clean Prod 148:571-582

Matkar K, Chapla D, Divecha J, Nighojkar A, Madamdar D (2013) Production of cellulase by a newly isolated strain of Aspergillus sydowii and its optimization under submerged fermentation. Inter Biodeter Biodegrad 78:24-33

Miller GL (1959) Use of dinitrosalicyclic acid reagent for determination of reducing sugar. Anal Chem 31:426-428

Mohana S, Shah A, Divecha J, Madamwar D (2008) Xylanase production by Burkholderia sp. DMAX strain under SSF using distillery spent wash. Bioresour Technol 99:7553-7564

Mohana S, Acharya BK, Madamwar D (2009) Distillery spent wash: treatment technologies and potential applications. J Hazard Mater 163:12-25

Mohapatra S, Padhy S, Mohapatra PKD, Thatoi HN (2018) Enhanced reducing sugar production by saccharification of lignocellulosic biomass, Pennisetum species through cellulase from a newly isolated Aspergillus fumigatus. Bioresour Technol 253:262-272

Murao S, Sakamoto R, Arai M (1988) Cellulases of Aspergillus aculeatus. In: Methods in enzymology, vol 160. Academic Press, pp 274-299

Nair SG, Sindhu R, Shashidhar S (2008) Fungal xylanase production under solid state and submerged fermentation conditions. Afr J Microbiol Res 2(4):82-86

Nandy T, Shastry S, Kaul SN (2002) Wastewater management in a cane molasses distillery involving bioresource recovery. J Environ Manag 65:25-38

Ncube T, Howard RL, Abotsi EK, Jansen van Rensburg EL, Ncube I (2012) Jatropha carcus seed cake as a substrate for production of xylanase and cellulase by Aspergillus niger FGSCA 733 in solid state fermentation. Ind Crops Prod 37:118-123

Papagianni M (2004) Fungal morphology and metabolite production in submerged mycelia process. Biotechnol Adv 22:189-259

Pettigrew L, Blomenhofer V, Hubert S, Groß F, Delgado A (2015) Optimisation of water usage in a brewery clean-in-place system using reference nets. J Clean Prod 87:583-593 
Pirt SJ (1975) Principles of microbe and cell cultivation. Blackwell, Oxford

Saha NK, Balakrishnan M, Batra VS (2005) Improving industrial water use: case study for an Indian distillery. Res Conser Recycl 43:163-174

Shahriarinour M, Ramanan RN, Wahab MNBA, Mohamad RB, Mustafa S, Ariff AB (2011) Improved cellulase production by Aspergillus terreus using oil palm empty fruit bunch fibre as substrate in a stirred tank bioreactor through optimization of the fermentation conditions. BioResources 6(3):2663-2675

Shrivastava SK, Gopalkrishnan KS, Ramchandran KB (1984) Kinetic characterization of crude b-glucosidase from A. wentii Pt 2804. Enzyme Microbial Technol 6:508-512

Singh A, Bishnoi NR (2013) Ethanol production from pretreated wheat straw hydrolyzate by Saccharomyces cerevisiae via sequential statistical optimization. Ind Crops Prod 41:221-226

Singh A, Bajar S, Bishnoi N, Singh N (2010) Laccase production by Aspergillus heteromorphus using distillery spent wash and lignocellulosic biomass. J Hazard Mater 176:1079-1082
Sreena CP, Sebastian D (2018) Augmented cellulase production by Bacillus subtilis strain MU S1 using different statistical experimental designs. J Genet Eng Biotehnol 16:9-16

Weber B, Stadlbauer EA (2017) Sustainable paths for managing solid and liquid waste from distilleries and breweries. J Clean Prod 149:38-48

Xu ZH, Bail YL, Xu X, Shi JS, Tao WI (2005) Production of alkalitolerant cellulase-free xylanase by Pseudomonas sp. UN024 with wheat bran as the main substrate. World J Microbiol Biotechnol 21:575-581

Publisher's Note Springer Nature remains neutral with regard to jurisdictional claims in published maps and institutional affiliations. 